MaPan : Jurnal Matematika dan Pembelajaran

p-ISSN: 2354-6883 ; e-ISSN: 2581-172X

Volume 4, Nomor 2, Desember 2016

\title{
EFEKTIVITAS PENERAPAN METODE EKSPOSITORI BERBASIS KUIS TERHADAP HASIL BELAJAR MATEMATIKA SISWA KELAS VIII MTsN MA' R A N G KABUPATEN PANGKEP
}

\author{
Muh. Rizal M. ${ }^{1)}$, Thamrin Tayeb2), Nurkholisah Latuconsina ${ }^{3)}$ \\ 1,2,3Fakultas Tarbiyah dan Keguruan UIN Alauddin Makassar \\ 1,2,3Kampus II: Jalan H. M. Yasin Limpo Nomor 36 Samata-Gowa \\ E-mail: rizal.m@gmail.com ${ }^{1)}$, thamrinthayeb@yahoo.com ${ }^{2}$, \\ nurkhalisaltc99@gmail.com ${ }^{3}$
}

\begin{abstract}
Abstrak
Penelitian ini bertujuan untuk mengetahui apakah penerapan metode ekspositori berbasis kuis efektif dalam meningkatkan hasil belajar matematika siswa kelas VIII MTsN Ma'rang Kabupaten Pangkep. Penelitian ini merupakan jenis penelitian quasi experiment dengan desain nonequivalent control group desain. Teknik analisis data yang digunakan adalah statistik deskriptif dan statistik inferensial. Berdasarkan hasil analisis data deskriptif diperoleh hasil belajar matematika siswa kelas VIII MTsN Ma'rang Kabupaten Pangkep bahwa persentase terbesar hasil belajar siswa yang diajar dengan menggunakan metode konvensional berada pada kategori tinggi $(52,17 \%)$ dan persentase terbesar hasil belajar siswa yang diajar dengan menerapkan metode ekspositori berbasis kuis berada pada kategori tinggi (56,52\%). Sedangkan pada hasil analisis statistik inferensial diperoleh nilai rata-rata kedua kelompok yaitu kelas kontrol sebesar 26,96 sedangkan pada kelas eksperimen sebesar 47,78 thitung $=10,47>$ ttabel $=2,02$ (thitung $>$ ttabel). Dengan demikian terdapat perbedaan rata-rata tingkat hasil belajar matematika antara kelas yang diajar dengan menerapkan metode ekspositori berbasis kuis dengan kelas yang diajar dengan menggunakan metode konvensional pada siswa kelas VIII MTsN Ma'rang. Metode ekspositori berbasis kuis efektif dalam meningkatkan hasil belajar matematika siswa kelas VIII MTsN Ma'rang yang berdasarkan pada hasil analisis inferensial dengan menggunakan rumus efisiensi relatif diperoleh nilai $\mathrm{R}<1,(0,63)<1$.
\end{abstract}

Kata Kunci : Hasil Belajar, Metode Eksipositori

$\mathrm{P}$ endidikan mempunyai peranan yang sangat menentukan bagi perkembangan dan perwujudan dari setiap individu, terutama bagi pembangunan bangsa dan negara. Kemajuan suatu kebudayaan bergantung kepada cara kebudayaan tersebut mengenali, menghargai, dan memanfaatkan sumber daya manusia dan hal ini berkaitan erat dengan kualitas pendidikan yang diberikan kepada anggota masyarakat. 
Matematika sebagai wahana ilmu pengetahuan memegang peranan penting dalam pendidikan. Mempelajari matematika merupakan salah satu sarana berpikir ilmiah dan logis serta mempunyai peranan penting dalam upaya peningkatan kualitas sumber daya manusia. Mengingat pentingnya matematika sebagai ilmu dasar, maka pembelajaran matematika diberbagai jenjang pendidikan formal perlu mendapat perhatian yang serius.

Matematika diperlukan siswa sebagai dasar memahami konsep berhitung, mempermudah dalam mempelajari mata pelajaran lain, dan memahami aplikasi matematika dalam kehidupan sehari-hari. Akan tetapi, pada kenyataannya banyak siswa merasa takut, enggan dan kurang tertarik terhadap mata pelajaran matematika. Penggunaan ilmu matematika tidak akan pernah lepas dari kehidupan sehari-hari seperti perdagangan, ekonomi, teknologi, dan lain sebagainya. Demikian pentingnya, matematika juga dijuluki sebagai Queen of Sciences, ratunya para ilmu. Selain itu pada ilmu-ilmu sains, matematika itu memiliki peranan penting sebagai sebuah ilmu terapan. Sehingga keterampilan menggunakan matematika dibutuhkan oleh setiap orang untuk memecahkan masalah dalam berbagai bidang kehidupan. Penguasaan matematika membutuhkan ketertarikan dan ketekunan yang khusus dalam mempelajarinya. Hal itu disebabkan matematika memiliki konstruksi keilmuan yang berbeda dengan ilmu lainnya. Oleh karena itu, seseorang tidak akan pernah terlepas dari ilmu matematika karena berkaitan langsung dengan kehidupannya sehari-hari. Sejalan dengan kurikulum 2013 yang sekarang digunakan dalam dunia pendidikan, menekankan pentingnya proses pembelajaran, tidak sekedar hasilnya.

Kurikulum 2013 juga memfokuskan pada pemerolehan kompetensikompotensi tertentu oleh siswa. Kurikulum ini mencakup sejumlah kompetensi, dan seperangkat tujuan pembelajaran yang dinyatakan sedemikian rupa, sehingga pencapaian dapat diamati dalam bentuk perilaku peserta didik sebagai suatu kriteria keberhasilan. Kegiatan pembelajaran perlu diarahkan untuk membantu peserta didik menguasai sekurang-kurangnya tingkat kompetensi minimal agar mereka dapat mencapai tujuan yang telah ditetapkan. Oleh karena itu, guru harus mampu membawa siswanya kepada tujuan yang ingin dicapai dalam proses pembelajaran.

Suatu Negara dapat mencapai suatu keberhasilan jika kualitas pendidikannya sangat berkualitas, sehingga dengan keberhasilan tersebut akan menjadikan negara tersebut lebih maju dengan pesat. Mengingat akan pentingnya pendidikan didalam kehidupan, maka pendidikan harus 
dilaksanakan dengan sebaik-sebaiknya. Salah satu fenomena yang menunjukkan hasil belajar matematika siswa memprihatinkan adalah proses pembelajaran yang masih menggunakan metode konvensional. Fenomena pembelajaran yang pernah dialami oleh setiap individu hingga saat ini adalah metode belajar konvensional yang cenderung menyerupai bentuk dan gaya pabrik: mekanisme, standardisasi, kontrol luar, satu ukuran untuk semua format, "Aku bicara kau mendengar". Model ini pada zaman itu ternyata dianggap paling hebat, kalau tidak mau dikatakan sebagai satu-satunya cara untuk mempersiapkan pekerja menjalani kehidupan yang membosankan dalam pekerjaan di lingkungan industri. Model belajar seperti ini menjadikan pembelajaran jadi produk yang penurut, kurang kritis, menghafal materi pelajaran atau perkuliahan. Akibatnya, kadang-kadang muncul ketegangan dalam diri mereka, kecemasan akan masa depan. kurang percaya diri, minder, muncul ketakutan yang berlebihan, dan lain-lain. Oleh karena itu, seorang guru harus memilih suatu model, metode, maupun strategi dalam pembelajaran yang sesuai agar siswa dengan mudah memahami materi pembelajaran.

Metode pengajaran merupakan suatu komponen didalam kurikulum matematika. Di dalam proses belajar, pengikutsertaan siswa secara aktif dapat berjalan secara efektif, bila pengorganisasian dan penyampain materi sesuai dengan kesiapan mental siswa. Sehingga guru harus cerdas dalam memilih metode yang tepat yang disesuaikan dengan kebutuhan siswa dalam kondisi dan suasana belajar siswa. Selain peranan guru dalam proses belajar mengajar, siswa juga memiliki peranan yang sangat penting. Peranan siswa adalah: (1) pencari informasi yang benar, (2) pemakai media dan sumber yang benar, (3) menyelesaikan tugas dengan penilaian guru.

Menurut Koontz \& Plank dalam Maurer bahwa peningkatan penggunaan metode pembelajaran dibutuhkan siswa untuk menjadi akrab dengan konten yang akan dibahas. Siswa tidak dapat memberikan kontribusi dalam diskusi atau berpartisipasi dalam debat, permainan peran atau kegiatan lain jika mereka tidak menyelesaikan bacaan yang ditugaskan sehingga dipahami dasar konsep yang sedang dibahas. Selain penggunaan metode ekspositori, keaktifan siswa sangat berpengaruh terhadap hasil belajar siswa. Oleh karena itu pembelajaran dengan metode ekspositori perlu dikemas agar dapat membuat siswa lebih aktif belajar. Salah satu metode yang efektif untuk meningkatkan keaktifan siswa adalah dengan adanya pemberian kuis. 
Permainan kuis adalah metode dalam pembelajaran yang berupa permainan kuis, yaitu ada soal/pertanyaan yang harus diselesaikan. Pengaruh kuis mingguan sangat bermanfaat terhadap prestasi siswa dalam beberapa cara. Pertama, mereka menyediakan motivasi bagi siswa untuk menghadiri kelas-kelas. Hasil penelitian menunjukkan bahwa kehadiran siswa meningkat sebesar 10 persen ketika kuis diadakan. Selain itu, banyak penelitian telah menunjukkan bahwa sering melakukan pengujian meningkatkan kehadiran siswa di kelas menurut Bauer, Alex, Jones, Wilder, Banjir, \& Stromsnes. Penggunaan kuis tidak hanya berpengaruh terhadap motivasi belajar siswa, akan tetapi juga berperangaruh terhadap hasil dan minat belajar siswa untuk terus diadakan kuis.

Para pendukung kuis percaya bahwa kuis memiliki keunggulan tak terbantahkan, kuis membantu siswa untuk mempertahankan konsep untuk waktu yang cukup lama. Pengujian sering juga menguntungkan karena dengan sering memberikan siswa kuis, sekolah dapat memperoleh informasi berharga tentang pemahaman mereka. Selain itu, sering pengujian dapat memberikan sekolah, guru, orang tua, dan siswa dengan umpan balik yang berguna tentang kinerja siswa di kelas. Salah satu keuntungan penting pengujian adalah bahwa hal itu menciptakan motivasi ekstrinsik bagi siswa; karena siswa ingin mendapatkan nilai bagus dalam kursus, mereka berusaha keras dan menghabiskan banyak waktu untuk mempersiapkan kuis menurut Dustin.

Seperti halnya hasil penelitian yang dilakukan oleh Siami Rohmah pada siswa kelas V SDN 1 Ngrencak Kecamatan Panggul Kabupaten Trenggalek tahun 2011 bahwa metode permainan kuis dapat meningkatkan keaktifan belajar matematika di kelas V SDN 1 Ngrencak Kecamatan Panggul Kabupaten Trenggalek yaitu dari 2(9\%) siswa yang sangat aktif, 12(52\%) siswa aktif, dan 9(39\%) siswa kurang aktif menjadi $13(57 \%)$ siswa sangat aktif, $10(43 \%)$ siswa aktif, dan $0(0 \%)$ siswa kurang aktif dan metode permainan kuis dapat meningkatkan prestasi belajar matematika di kelas V SDN 1 Ngrencak Kecamatan Panggul Kabupaten Trenggalek yaitu pada nilai 61 keatas dari 7(30\%) siswa meningkat menjadi $19(83 \%)$ peserta didik.

Fakta menunjukkan bahwa hasil belajar matematika yang masih rendah diperoleh dari hasil wawancara dengan salah satu guru matematika di MTsN Ma'rang Kabupaten Pangkep yang menyampaikan bahwa dalam proses belajar mengajar sebagian besar siswa belum mengerti konsep materi yang diberikan meskipun dijelaskan secara berulang-ulang sehingga hasil belajar 
matematika yang diperoleh siswa masih banyak yang di bawah KKM (Kriteria Ketuntasan Minimum).

Berdasarkan hasil wawancara dengan salah satu siswa di MTsN Ma'rang Kabupaten Pangkep pada pembelajaran matematika di kelas, cara penyampaian materi ajar secara keseluruhan guru lebih aktif daripada siswa. Setelah guru menjelaskan materi pelajaran matematika, guru terkadang langsung memberikan soal kepada siswa untuk dikerjakan. Sehingga, kebanyakan siswa kurang mengerti materi yang diberikan dan merasa bosan dengan metode yang selalu dominan berpusat ke guru. Akibatnya. ketika dilakukan evaluasi belajar atau ulangan harian ternyata banyak siswa yang memperolah nilai dibawah KKM. Dari kejadian yang seperti ini, mereka menganggap bahwa matematika adalah pelajaran yang sangat susah dan sangat ditakuti dibanding pelajaran yang lainnya. Hal ini menunjukkan bahwa untuk mengatasi rendahnya hasil belajar siswa diperlukan suatu metode yang tepat agar siswa senang dan aktif dalam pembelajaran. Berdasarkan pada permasalahan tersebut, penulis termotivasi melaksanakan penelitian pembelajaran matematika dengan menggunakan metode ekspositori dengan pemberian kuis. Metode pembelajaran ekspositori dengan pemberian kuis matematika ini diharapkan dapat menjadi salah satu solusi dalam mengatasi rendahnya hasil belajar yang dialami oleh siswa.

\section{PENGERTIAN BELAJAR}

Belajar merupakan suatu proses adaptasi perilaku yang bersifat progresif, artinya bahwa sebagai akibat dari belajar adanya sifat progresivitas, adanya tendensi kearah yang lebih sempurna atau lebih baik dari keadaan sebelumnya. Belajar sebagai suatu proses kegiatan yang menimbulkan kelakuan baru atau merubah kelakuan lama sehingga seseorang lebih mampu memecahkan masalah dan menyesuaikan diri terhadap situasi-situasi yang dihadapi dalam hidupnya. Jadi belajar merupakan kegiatan yang dilakukan oleh hampir setiap orang. Pengetahuan, keterampilan, kebiasaan dan tingkah laku pada dasarnya dibentuk dan ditempuh melaui proses belajar, karena itu seseorang dikatakan belajar bila dapat diasumsikan dalam diri orang itu terjadi suatu proses kegiatan yang mengakibatkan suatu perubahan tingkah laku. yang berlangsung dalam interaksi aktif dalam lingkungan, yang menghasilkan perubahan-perubahan dalam pengelolaan pemahaman. 


\section{HAKEKAT MATEMATIKA}

Kata matematika berasal dari perkataan latin mathematica, yang mulanya diambil dari perkataan Yunani mathematike yang berarti "relating to learning". Perkataan itu mempunyai asal katanya mathema yang berarti pengetahuan atau ilmu (knowledge, science). Kata mathematike berhubungan pula dengan kata lainnya yang hampir sama, yaitu mathenein yang artinya belajar (berpikir).

Adapun ciri-ciri khusus matematika adalah sebagai berikut
a. Memiliki objek abstrak
b. Bertumpu pada kesepakatan
c. Berpola pikir deduktif
d. Memiliki simbol yang kosong dari arti
e. Konsisten dalam sistemnya

Tujuan pembelajaran matematika di sekolah adalah agar peserta didik memiliki kemampuan; (1) menggunakan penalaran pada pola dan sifat, melakukan manipulasi matematika dalam membuat generalisasi, menyusun bukti, atau menjelaskan gagasan dan pernyataan matematika, (2) memecahkan masalah yang meliputi kemampuan memahami masalah, merancang model matematika, menyelesaikan model dan menafsirkan solusi yang diperoleh, (3) mengomunikasikan gagasan dengan simbol, tabel, diagram, atau media lain untuk memperjelas keadaan atau masalah, (4) memiliki sikap menghargai kegunaan matematika dalam kehidupan, yaitu memiliki rasa ingin tahu, perhatian, dan minat dalam mempelajari matematika, serta sikap ulet dan percaya diri dalam pemecahan masalah.

Hasil belajar merupakan terjadinya perubahan tingkah laku pada diri seseorang yang dapat diamati dan diukur pada diri seseorang melalui pengetahuan, sikap, dan keterampilan yang dimilikinya. Adapun hasil belajar ini sangat penting manfaatnya untuk mengetahui sejauh mana tingkat keberhasilan siswa dalam belajar.

\section{METODE EKSPOSITORI BERBASIS KUIS}

\section{Pengertian Metode Ekspositori Berbasis Kuis}

Metode ekspositori berbasis kuis merupakan perpaduan antara metode ekspositori dan metode permainan kuis. Metode Ekspositori adalah metode pembelajaran yang menekankan pada proses penyampaian materi secara verbal dari seorang guru kepada sekelompok siswa dengan maksud agar siswa dapat menguasai materi pelajaran secara optimal. Sedangkan permainan 
kuis adalah metode dalam pembelajaran yang berupa pemberian kuis, yaitu ada soal/pertanyaan yang harus diselesaikan.

\section{Prinsip Penggunaan Metode Ekspositori Berbasis Kuis}

Dalam penggunaan metode ekspositori berbasis kuis terdapat hal yang harus diperhatikan oleh setiap guru yakni sebagai berikut:
a. Berorientasi pada tujuan
b. Prinsip komunikasi
c. Prinsip kesiapan
d. Prinsip berkelanjutan

\section{METODE PENELITIAN}

Jenis dari penelitian ini adalah eksperimen semu. Penelitian ini dilakukan di MTsN Ma'rang Pangkep, alamatnya di Jalan Raya Talaka KM 65, Kelurahan Talaka, Kecamatan Ma'rang, Kabupaten Pangkep, Provinsi Sulawesi Selatan. Populasi dalam penelitian ini adalah keseluruhan obyek yang akan diteliti dengan segala karakteristik yang dimilikinya yakni siswa kelas VIII MTsN Ma'rang Kabupaten Pangkep. Sampel dalam penelitian ini adalah siswa kelas VIIIB sebagai kelas kontrol dan kelas VIIIC sebagai kelas eksperimen di MTsN Ma'rang Kabupaten Pangkep yang masing-masing terdiri atas 23 orang.

Tes hasil belajar matematika siswa kelas VIIIB dan VIIIC adalah tes sebelum perlakuan (pretest) dan tes setelah perlakuan (posttest). Bentuk tes yang diberikan adalah uraian.

Ada dua macam statistik yang digunakan untuk analisis data dalam penelitian, yaitu statistik deskriptif dan statistik inferensial. Uji prasyarat dalam penelitian ini adalah uji normalitas, uji homogenitas dan pengujian hipotesis dilanjtkan dengan uji efektivitas.

\section{HASIL PENELITIAN DAN PEMBAHASAN}

Berdasarkan pretest dan posttest yang diberikan pada siswa di kelas kontrol tanpa menggunakan metode Ekspositori Berbasis Kuis pada proses pembelajaran di kelas VIII B sebagai berikut: 
Tabel 1: Rekapitulasi Hasil Belajar pada Kelas Kontrol

\begin{tabular}{ccc}
\hline \multirow{2}{*}{ Statistik } & \multicolumn{2}{c}{ Nilai Statistik Kelas Kelas VIII B } \\
\cline { 2 - 3 } & PretestKelas Kontrol & Posttest Kelas Kontrol \\
\hline Jumlah Sampel & 23 & 23 \\
Nilai Terendah & 20 & 41 \\
Nilai Tertinggi & 55 & 82 \\
\hline
\end{tabular}

Berdasarkan tabel di atas, maka dapat diketahui bahwa skor maksimum yang diperoleh pretest tanpa menggunakan metode ekspositori berbasis kuis pada kelas kontrol adalah 55, sedangkan minimum adalah 20 . Skor maksimum yang diperoleh posstest tanpa menggunakan metode Ekspositori Berbasis Kuis di kelas kontrol adalah 82 sedangkan skor minimum adalah 41.

Tabel 2. Distribusi Frekuensi dan Persentas Hasil Belajar Matematika Pretest dan posttest Kelas Kontrol

\begin{tabular}{|c|c|c|c|c|c|}
\hline \multirow{2}{*}{ Interval } & \multirow{2}{*}{ Kategori } & \multicolumn{2}{|c|}{ Pretest Kelas Kontrol } & \multicolumn{2}{|c|}{ Posttest Kelas Kontrol } \\
\hline & & Frekuensi & Persentase (\%) & Frekuensi & Persentase (\%) \\
\hline $0-20$ & $\begin{array}{l}\text { Sangat } \\
\text { Rendah }\end{array}$ & 1 & 4,35 & 0 & 0 \\
\hline $21-40$ & Rendah & 15 & 65,33 & 0 & 0 \\
\hline $41-60$ & Sedang & 7 & 30,43 & 10 & 43,48 \\
\hline $61-80$ & Tinggi & 0 & 0 & 12 & 52,17 \\
\hline $81-100$ & $\begin{array}{c}\text { Sangat } \\
\text { Tinggi }\end{array}$ & 0 & 0 & 1 & 4,35 \\
\hline \multicolumn{2}{|c|}{ JUMLAH } & 23 & 100 & 23 & 100 \\
\hline
\end{tabular}

Berdasarkan tabel di atas, dapat dilihat bahwa hasil belajar matematika pretest pada kelas kontrol terdapat 1 siswa $(4,35 \%)$ berada pada kategori sangat rendah, 15 siswa $(65,22 \%)$ berada pada kategori rendah, 7 siswa $(30,43 \%)$ berada pada kategori sedang, dan tidak ada siswa berada pada kategori tinggi dan sangat tinggi. Jadi, dapat disimpulkan bahwa persentase terbesar hasil belajar matematika siswa pretest pada kelas kontrol berada pada kategori rendah. Sedangkan hasil belajar posttest pada kelas kontrol tidak terdapat siswa berada pada kategori sangat rendah dan rendah , 10 siswa $(43,48 \%)$ pada kategori sedang, 12 siswa $(52,17 \%)$ berada pada kategori tinggi, dan 1 siswa $(4,35 \%)$ berada pada kategori sangat tinggi. Jadi, dapat disimpulkan bahwa persentase terbesar hasil belajar matematika siswa posttest pada kelas kontrol berada pada kategori tinggi. 
Berdasarkan pretest dan posttest yang diberikan pada siswa di kelas eksperimen yang diajardengan menggunakan metode ekspositori berbasis kuis di kelas VIIIc mata pelajaran Matematika didapatkan hasil sebagai berikut:

Tabel 3. Rekapituasi Hasil Belajar Peserta Didik pada Kelas Eksperimen

\begin{tabular}{ccc}
\hline \multirow{2}{*}{ Statistik } & \multicolumn{2}{c}{ Nilai Statistik Kelas VIII B } \\
\cline { 2 - 3 } & $\begin{array}{c}\text { Pretest } \\
\text { Eksperimen }\end{array}$ & $\begin{array}{c}\text { Posttest } \\
\text { Eksperimen }\end{array}$ \\
\hline Jumlah Sampel & 23 & 23 \\
Nilai Terendah & 15 & 60 \\
Nilai Tertinggi & 50 & 69 \\
\hline
\end{tabular}

Berdasarkan tabel di atas, maka dapat diketahui bahwa skor maksimum yang diperoleh pada pretest dan posttest dengan menggunakan metode ekspositori berbasis kuis dalam pembelajaran pada kelas eksperimen masing-masing 50 dan 95, sedangkan skor minimum yang diperoleh pada pretest dan posttest adalah 15 dan 60.

Tabel 4: Distribusi Frekuensi dan Persentase Hasil Pretest dan Posttest pada Kelas Eksperimen

\begin{tabular}{|c|c|c|c|c|c|}
\hline \multirow[b]{2}{*}{ Interval } & \multirow[b]{2}{*}{ Kategori } & \multicolumn{2}{|c|}{ Pretest kelas kontrol } & \multicolumn{2}{|c|}{ Posttest Kelas Kontrol } \\
\hline & & Frekuensi & $\begin{array}{c}\text { Persentase } \\
(\%)\end{array}$ & Frekuensi & Persentase $(\%)$ \\
\hline $0-20$ & $\begin{array}{l}\text { Sangat } \\
\text { Rendah }\end{array}$ & 3 & 13,04 & 0 & 0 \\
\hline $21-40$ & Rendah & 15 & 65,33 & 0 & 0 \\
\hline $41-60$ & Sedang & 5 & 21,74 & 2 & 8,7 \\
\hline $61-80$ & Tinggi & 0 & 0 & 13 & 56,52 \\
\hline $81-100$ & $\begin{array}{l}\text { Sangat } \\
\text { Tinggi }\end{array}$ & 0 & 0 & 8 & 34,78 \\
\hline \multicolumn{2}{|c|}{ JUMLAH } & 23 & 100 & 23 & 100 \\
\hline
\end{tabular}

Berdasarkan tabel di atas, dapat dilihat bahwa hasil belajar pretest pada kelas eksperimen 3 siswa(13,04\%), berada pada kategori sangat rendah, 15 siswa $(75,22 \%)$ berada pada kategori rendah, 5 siswa $(21,74 \%)$ berada pada kategori sedang, dan tidak ada siswa berada pada kategori tinggi dan sangat tinggi. Jadi, dapat disimpulkan bahwa persentase terbesar hasil belajar matematika siswa pretest pada kelas eksperimen berada pada kategori rendah. Sedangkan hasil belajar postest pada kelas eksperimen tidak terdapat siswa 
berada pada kategori sangat rendah, rendah, 2 siswa $(8,70 \%)$ berada pada kategori sedang, 13 siswa (56,52\%) berada pada kategori tinggi dan 8 siswa $(34,78 \%)$ pada kategori sangat tinggi.Jadi, dapat disimpulkan bahwa persentase terbesar hasil belajar matematika siswa posttest pada kelas eksperimen berada pada kategori tinggi.

Hasil pengujian normalitas pretest dan posttest kelas kontrol beserta kelas ekperimen menunjukkan bahwa keseluruhan data berdistribusi normal. Selanjutnya hasil uji homogenitas menunjukkan bahwa data homogen. Uji hipotesis menunjukkan bahwa thitung $=10,47$ dan harga $\mathrm{t}$ tabel dengan $\propto=$ 0,05 dan $d k=(23+23-2)=44$ adalah 2,02. Karena thitung $>t$ tabel $(10,47>2,02)$ maka dapat disimpulkan bahwa Ho ditolak, ini berarti bahwa terdapat perbedaan rata-rata tingkat hasil belajar antara kelas yang diajar menggunakan metode ekspositori berbasis kuis dengan kelas yang diajar tanpa menggunakan metode ekspositori berbasis kuis terhadap hasil belajar matematika siswa kelas VIII MTsN Ma'rang Kabupaten Pangkep.

Pada penelitian ini diperoleh hasil bahwa terjadi peningkatan hasil belajar matematika yang diajar dengan menggunakan metode ekspositori berbasis kuis dibandingkan dengan yang diajar tanpa menggunakan metode ekspositori berbasis kuis. Pada kedua kelas tersebut, terlihat jelas bahwa pada posttest kelas kontrol mengalami peningkatan pada kategori sedang dan tinggi, dan mengalami penurunan persentase pada kategori sangat tinggi, sedangkan pada hasil posttest kelas eksperimen terjadi peningkatan yang cukup maksimal pada kategori tinggi. Jadi, dapat disimpulkan bahwa terjadi peningkatan ratarata hasil belajar matematika siswa pada kelas yang diajar dengan menggunakan metode ekspositori berbasis kuis.

Hasil Belajar matematika siswa tanpa menggunakan metode ekspositori berbasis kuis dapat kita lihat secara deskriptif pada hasil penelitian bahwa hasil belajar matematika siswa masih rendah disebabkan proses pembelajaran selama ini hanya berpusat diguru dan pasif dan hanya mendengarkan penjelasan dari guru tanpa mengetahui konsep dasarnya. Karena siswa belum terlalu dilibatkan secara aktif sehingga guru sulit untuk mengembangkan atau meningkatkan pembelajaran yang benar-benar berkualitas sehingga siswa lebih lambat dan malas untuk memahami materi.

Hasil belajar matematika siswa dengan menggunakan metode ekspositori berbasis kuis dapat kita lihat secara deskriptif pada hasil penelitian bahwa hasil belajar matematika siswa berada pada kategori tinggi. Hal ini disebabkan metode pembelajaran yang digunakan mampu membuat siswa 
benar-benar ikut berpartisipasi dalam pembelajaran dengan penggunaan aktivitas yang terus-menerus, mendorong siswa untuk berpikir dan menjelaskan pemahaman mereka, sehingga pembelajaran lebih bermakna, dimana siswa tidak sekedar menghapal rumus, akan tetapi siswa dapat menemukan sendiri, mampu mengembangkan konsep, dapat menerapkan dalam kehidupan dan dapat mentransfer dalam bentuk baru sehingga siswa menjadi aktif dalam pembelajaran dan dapat mengkontruksi sendiri pengetahuannya dengan melibatkan masalah dalam kehidupan sehari-hari. seiring dengan bertambahnya pertemuan siswa juga semakin aktif dalam bertanya maupun dalam pembahasan soal, dan siswa yang melakukan aktivitas lain saat pembelajaran semakin berkurang dan kemampuan mengerjakan soal-soal juga meningkat.

Selain itu, untuk menarik minat siswa dalam memahami konsepkonsep yang tercakup dalm pembelajaran tidaklah mudah. Guru dituntut mampu memiliki dan menggunakan media pembelajaran sesuai dengan materi yang akan disajikan, dituntut mampu menggunakan metode mengajar secara stimulus untuk menghidupkan suasana pengajaran dengan baik. Pemilihan metode belajar yang tepat akan membantu siswa menumbuhkan minat yang ada dalam dirinya sehingga meningkatkan rasa senang, perhatian, kemauan dan kesadaran belajar.

Penelitian ini juga didukung oleh beberapa penelitian sebelumnya, salah satunya penelitian yang dilakukan oleh Anna Rilatul Hannifah tentang "metode ekspositori dengan pemberian kuis sebagai upaya peningkatan motivasi belajar matematika siswa kelas IX Penjualan SMK Negeri 7 Yogyakarta". Hasil penelitian tersebut diperoleh bahwa berdasarkan perolehan nilai siswa sebelum dan sesudah pembelajaran dengan metode ekspositori dengan pemberian kuis, diketahui terdapat peningkatan motivasi belajar matematik siswa. Hal ini menunjukkan bahwa siswa dengan pembelajaran metode ekspositori berbasis kuis memberikan perolehan hasil yang lebih baik dalam kemampuan pemahaman matematik daripada siswa yang pembelajarannya secara konvensional.

Berdasarkan penjelasan di atas dan penelitian terdahulu yang relevan dengan penelitian ini, hal ini berarti mendukung diterimanya hipotesis yaitu metode ekspositori berbasis kuis efektif dalam meningkatkan hasil belajar matematika siswa kelas VIII MTsN Ma'rang Kabupaten Pangkep. 


\section{SIMPULAN}

Berdasarkan hasil penelitian dan pembahasan pada penelitian ini, maka diperoleh beberapa kesimpulan sebagai berikut:

a. Hasil belajar siswa kelas VIIIB yang diajar tanpa menggunakan metode ekspositori berbasis kuis memiliki presenta sesebesar $43,48 \%$ berada pada kategori sedang, 52,17\% berada pada kategori tinggi dan 4,35\% berada pada kategori sangat tinggi dengan nilai rata-rata yang diperoleh sebesar $61,96$.

b. Hasil Belajar matematika siswa kelas VIIIB yang diajar dengan menggunakan metode ekspositori berbasis kuis memiliki presentase sebesar $8,70 \%$ berada pada kategori sedang, 56,52\% berada pada kategori tinggi dan 34,78\% berada pada kategori sangat tinggi dengan nilai rata-rata yang diperoleh sebesar 78,93.

c. Metode Ekspositori Berbasis Kuis efektif dalam meningkatkan hasil belajar matematika siswa kelas VIII MTsN Ma'rang Kabupaten Pangkep yang berdasarkan pada hasil analisis inferensial dengan menggunakan rumus efisiensi relatif diperoleh nilai $R<1,(0,63)<1$.

\section{DAFTAR PUSTAKA}

Abdurrahman, M. (2003). Pendidikan Bagi Anak Berkesulitan Belajar. Jakarta: Rineka Cipta.

Ahmadi , A., \& Prasetyo, J. T. (2005).Strategi Pembelajaran Untuk Fakultas Tarbiyah Komponen MKDK. Bandung: Pustaka Setia.

Arikunto, S. (2013). Prosedur Penelitian atau Pendekatan Praktik. Cet XV; Jakarta: Rineka Cipta.

Arsana, M. R. (2014). Pengaruh Metode Ekspositori yang Dikombinasikan dengan Mind Mapping Terhadap Hasil Belajar IPA. e-Jurnal Mimbar PGSD UPG. Vol .2, No. 1.

Dimyati, \& Mudjiono. (2009). Belajar dan Pembelajaran. Jakarta: Rineka Cipta.

Emzir. (2010). Metodologi Penelitian Pendidikan Kuantitatif \& Kualitatif. Jakarta: Rajawali.

Gholami, V. (2013). The Effect of Weekly Quizzes on Students' Final Achievement Score. International Journal of education. 
Hamsiah, S. (2003). Psikologi Pembelajaran Matematika. Makassar: Alauddin Universitas Press.

Hasratuddin. (2013). Membangun Karakter Melalui Pembelajaran Matematika. Jurnal pendidikan matematika.

Hasan, I. (2010). Pokok-pokok Materi Statistik 2 (Statistik Inferensial). Cet VI. Jakarta: PT BumiAksara.

Hudojo, H. (1988). Mengajar Belajar Matematika. Jakarta: Departemen Pendidikan dan Kebudayaan.

Ibe. (2013). Effects of Guided-Inquir and Expository Teaching Methods on Senior Secondary School Students' Performances in Biology in Imo State. Journal of education Vol.2, No. 4.

Majid, A. (2013). Strategi Pembelajaran. Bandung: PT. Remaja Rosdakarya.

Matondang, Z. (2009). Pengujian Homogenitas Varians Data. Medan: Taburasa PPS UNIMED.

Maurer. (2013). Using Reading Guides and On-line Quizzes to Improve Reading Compliance and Quiz Scores. International Journal of education.

Mubarok, M. (2008). BCM: Rahasia Cerdas Belajar sambil Bermain. Surabaya: Java Pustaka.

Muhkal, M. (1999). Matematika sekolah sebagai wahana pendidikan. Eksponen. Jurnal Pendidikan Matematika.

Mulyasa, E. (2013). Pengembangan dan Implementasi Kurikulum 2013. Bandung: Remaja Rosdakarya.

Nasir, M. (2003). Metode Penelitian. Cet. I; Jakarta: Ghalia Indonesia.

Riduwan. (2008). Belajar Mudah Penelitian Untuk Guru, Karyawan, dan Peneliti Pemula. Bandung: Alfabeta.

Rohmah, S. (2011). Penggunaan Metode Permainan Kuis Untuk Meningkatkan Keaktifan Dan Prestasi Belajar Matematika Materi Pokok Bangun Datar Dan Bangun Ruang Peserta Didik Kelas V SDN I Ngrencak Panggul Trenggalek. (Tulungagung: Skripsi Tidak Diterbitkan). 
Rusman. (2012). Model-model Pembelajaran.Jakarta:PT. Raja Grafindo Persada.

Sahabuddin. (1999). Mengajar dan Belajar. Makassar: Badan Penerbit Universitas Negeri Makassar.

Sangadji, E. M., \& Sophiah. (2010). Metodologi Penelitian. Malang: Andi.

Siregar, S. (2011). Statistik Deskriptif untuk Penelitian. Cet. I; Jakarta: Raja Grafindo Pusaka.

Sudirman. (1991). Ilmu Pendidikan. Bandung: Remaja Rosdakarya.

Sugiyono. (2009). Metode Penelitian Kuantitatif Kualitatif dan RED. Cet. VI; Bandung:Alfabeta.

Suherman, E. (2003). Strategi Pembelajaran Matematika Kontemporer. Bandung: Jurusan Pendidikan Matematika FMIPA Universitas Pendidikan Indonesia.

Sudjana, N. (2004). Dasar-dasar Proses Belajar mengajar. Cet VII; Bandung: Sinar Baru Algesindo.

Sujarweni, W. (2014). Metodologi Penelitian. Yogyakarta: Pustaka Baru.

Sukmadinata, N. S. (2009). Landasan Psikologi Proses Pendidikan. Bandung: Remaja Rosdakarya.

Tiro, M. A. (2008). Dasar-dasar Statistik. Ed.3; Makassar: State University Of Makassar Press.

Walgito. (1980). Bimo Pengantar Psikologi Umum. Yogyakarta: Andi.

Widiari, M. (2014). Pengaruh Metode Pembelajaran Mind Mapping dan Ekspositori Terhadap Hasil Belajar Matematika. Jurnal pendidikan. Vol. 2, No. 1.h.3. 